\title{
Fibre Characterization of Cassava Peel Leaf Meal and Its Utilization by Broilers
}

\section{${ }^{1}$ KEHINDE, AS; $* 2$ BABATUNDE, TO; ${ }^{3}$ KEHINDE, JO; ${ }^{3}$ BABATUNDE, OO; ${ }^{4}$ ADELAKUN, KM; ${ }^{1}$ FADIMU, BO; ${ }^{1}$ ABDULAZEEZ, FI; ${ }^{1}$ OGUNDIMU, AO}

\author{
*IDepartment of Wildlife and Ecotourism, Forestry Research Institute of Jericho, Ibadan Oyo State, Nigeria. \\ ${ }^{2}$ Department of Forestry Technology, Federal College of Forestry Jericho, Ibadan Oyo State, Nigeria. \\ ${ }^{3}$ Department of Wood and Paper Technology, Federal College of Forestry, Jericho Ibadan Oyo State, Nigeria. \\ ${ }^{4}$ Federal College of Wildlife Management, PMB 268 New Bussa, Niger State. \\ *Corresponding Author Email:sollybee2012@gmail.com; Tel: +2348033948859
}

\begin{abstract}
One hundred and twenty $(\mathrm{n}=120)$ day old broiler chicks with an average weight $(100.00 \pm 7.00 \mathrm{~g})$ were randomly allotted to four dietary treatments, with cassava peel leaf meal (CPLM) as replacement for maize at (starter and finisher phases).The trial was in three phases of adaptation (1-2week),starter (3-5week) and finisher (69 week).Thirty broilers chicks were assigned to each of the four treatments, while was replicated three times at 10 chicks each. Performance of the chicks such weight gain, feed intake and carcass yield was evaluated and the proximate and fiber quality of the diets and CPLM were also determined. Data obtained for performance evaluated was analyzed using ANOVA, while significant means were separated by SAS of the same package. The outcome revealed that CPLM had $(89.93 \%)$ dry matter, $(18.93 \%)$ crude protein and $(43.28 \%) \mathrm{NDF}$, with anon-significant $(\mathrm{p}<0.05)$ variation in weight gain, enhanced $(\mathrm{p}<0.05)$ feed intake and depressed $(\mathrm{p}<0.05)$ feed to gain ratio as CPLM inclusion increased. Dressing percentage values $(69.00-73.00 \%)$ were obtained on the treatments. CPLM inclusion $(0,15,30$ and $45 \%)$ as replacement for maize in the diets of broilers produced a favourable performance.
\end{abstract}

\section{DOI: https://dx.doi.org/10.4314/jasem.v24i9.7}

Copyright: Copyright (C) 2020 Kehinde et al. This is an open access article distributed under the Creative Commons Attribution License (CCL), which permits unrestricted use, distribution, and reproduction in any medium, provided the original work is properly cited.

Dates: Received: 25 August 2020; Revised: 25September 2020; Accepted: 20 September 2020

Keywords: Cassava peel, cassava leaf, fiber, broiler chicks

Poultry production holds a very good prospect of bridging the huge protein gap endemic in most developing countries (Aguihe et al., 2015), due to the peculiar attributes of domestic fowl and others in the poultry group. (Oluemi and Roberts, 2000). The production of meat and eggs within a short period will help in the eradication of ugly human development index obtained in Nigeria and other African countries, such as the rampant high mortality in children before the age of five years and nutrition related ailments (Kehinde et al., 2019).The expression of the potential of the industry is inhibited by the high cost of production, thus making poultry products beyond the reach of most people, aligning with the forces of demand and supply. When the price of a given commodity is high, the purchasing power of the people will reduce. The major factor responsible for the high cost is the high cost of feedstuffs, due to the competition between humans, animal and industry and their seasonal availability (Agbede et al., 2002).The cost of feed has been computed by nutritionists and farmers, to account for about $60-70 \%$ of the total cost of animal production, with the energy sources like maize, wheat offal and maize bran accounting for $50-$ $55 \%$ (Akinfala et al., 2019). The seeking of alternatives for this class of feedstuffs is the focus of most researchers (Brendon and Nnadi 2013 and Nsa et al., 2019). The most utilized alternatives are farm wastes and agro by-products, such as cassava peel, leaf, sieviate, chaff and tuber (Akinfala and Tewe 2001 and Adesehinwa et al., 2016). Most cassava products are low in crude protein, except the leaf that contains $30-35 \%$ crude protein, depending on the age at harvesting. Cassava peel and leaf were mixed in equal proportion by weight, to evolve a composite meal regarded as cassava peel-leaf meal (CPLM) the leaf and peel were mixed to improve the protein content of the meal. Cassava is a prominent crop in Nigeria and it is propagated in most of the six geopolitical zones. It has been widely reported that Nigeria is the highest producer and consumer of cassava in the world. (Agunbiade et al., 2012 and Olomu, 2011), the crop is available all year round and its processing for livestock feeding is simple. Cassava common processing methods include soaking, sun drying, sieving, fermentation and roasting (Kehinde 2009). In most processing centres, the byproducts constitute environmental menace, their subsequent use in feeding livestock will assist in keeping the environment clean and also create wealth. This trial 
attempted to incorporate cassava peel-leaf meal into broiler chick's rations, in an attempt to reduce cost of production and replace conventional energy sources in broiler diets with cassava peel leaf meal. Broilers are chicken raised for meat and are ready for table in six to seven weeks, due to their efficient feed conversion and fast growth rate. This trial was conceived to combine the good properties of cassava products and broiler chicken to boost protein production and consumption.

\section{MATERIALS AND METHODS}

Experimental Site: The trial was conducted in the poultry unit of Federal College of Wildlife Management, New Bussa, Niger State, Nigeria. It is located between longitude $7^{0} 03^{1}$ and $10^{0} 00 \mathrm{~N}^{1}$ and latitude $4^{0} 31^{1}$ and $4^{0} 33^{1} \mathrm{~W}$ (Adewetan et al., 1980). The trial lasted for nine weeks, covering life cycle feeding (Starter and Finisher phases).

Sourcing and Processing of Cassava Products: Cassava peel and leaves were sourced from farmers (post-harvest). They were sundried and later formed into composite meal, by mixing them in equal proportion by weight.

Experimental Chicks and Management: One hundred and twenty day old chicks used for the trial were sourced from a reputable commercial hatchery. The chicks were raised on deep litter system with wood shavens as the litter material. The trial was phased into 3. Week $1-2$ was for adaptation and the chicks were raised on common diets, with $24 \%$ crude protein and $2913 \mathrm{ME} \mathrm{kcal} / \mathrm{kg}$, followed by 2 phases of utilization of test ingredients (Starter phase, 3-5 weeks and finisher phase weeks $6-9$ ). Feed and water were offered to the bird's nutrition and routine operations, such as administration of antibiotics, dewormer, antistress and vaccination against Newcastle, gomboro and fowl pox were carried out.

Experimental Diets: Feeding trial was carried out at the starter and finisher phases, adopting cassava peel leaf meal (CPLM) as replacement for maize $(0,15,30$, and $45 \%$ ). The diets were compounded to be almost isocaloric and isonitrogenous.

Experimental Design and Performance Evaluation: The experimental birds were randomly allotted to four treatments at 30 chicks per treatment, while each was replicated three times at 10 chicks each. Known quantity of feed was served in each replicate and the left over was collected over a period of $24 \mathrm{hrs}$ and weighed to determine feed intake while weight gain was determined on a weekly basis. The feed conversion ratio was evaluated by dividing theweight gain by feed intake. The carcass yield was also determined.

Chemical Analysis: Cassava peel, leaf, starter and finisher diets were analyzed for their proximate and fiber composition, using the A.O.A.C (1995) and Van Soest et al., (1991) methods respectively.

Statistical Analysis: Data obtained for performance parameters were subjected to Analysis of Variance (ANOVA) by the method of Steel and Torrie (1980), while significant mean difference was separated by the Duncan's Multiple Range Test (Duncan, 1955).

\section{RESULTS AND DISCUSSION}

Table 1 shows the proximate and fibre fractions of cassava peel leaf meal (CPLM), which revealed dry matter $(87.93 \%)$, crude protein $(18.87 \%)$, crude fibre $(16.78 \%)$ and NDF (43.28\%). The gross composition of the diet adopted at the $1^{\text {st }}$ phase of the starter feeding regime is on table 2, which shows the component ingredients, their quantity and resultant crude protein $(24.04 \%)$ and metabolizable energy $(2913 \mathrm{kcal} / \mathrm{kg})$.

Table 1: Proximate and Fibre Fractions Analysis of Cassava Peel

\begin{tabular}{ll}
\multicolumn{2}{c}{ Leaf Meal } \\
\hline Parameters & Value \\
\hline Dry matter & 87.93 \\
Crude protein & 18.93 \\
Crude fat & 2.67 \\
Crude fibre & 16.78 \\
ADL & 9.81 \\
NDF & 43.28 \\
ADF & 32.97 \\
ADL & 11.04 \\
Hemicelluloses & 10.31 \\
Celluloses & 21.93 \\
\hline
\end{tabular}

Table 2: Gross Composition of Feed Fed to Broiler Chicks at Starter Phase ( $1-2$ Weeks)

\begin{tabular}{ll}
\hline Ingredient & Ouantity \\
\hline Maize $\%$ & 49.50 \\
GNC\% $\%$ & 12.00 \\
Fish meal\% & 9.00 \\
Bone meal\% & 4.00 \\
PKC\% & 10.00 \\
Salt $\%$ & 0.50 \\
Soya meal\% & 15.00 \\
Premix\% & 0.50 \\
Total(kg) & 100 \\
Crude protein $\%$ & 24.04 \\
MEKcal/Kg & 2,913 \\
\hline
\end{tabular}

Table 3 had the gross composition of all the diets adopted at the $2^{\text {nd }}$ phase of the starter feeding regime, all the diets were almost isonitrogenous and isocaloric $(2838$ - 2878 $\mathrm{kcal} / \mathrm{kg} \mathrm{ME})$. Table 4 elicited the proximate composition of CPLM based diets fed to broiler chicks at the $2^{\text {nd }}$ phase of the starter feeding regime, which revealed the proximate parameters such as crude protein, fibre, ether extract, ash and NFE) and 
dry matter $(90.67-90.81 \%)$. Table 5 had the gross composition of the experimental diets adopted at the finisher phase, which shows the feed ingredients, their quantity, estimated crude protein contents $(21.99$ $22.09 \%)$ and M.E values $(2,899-2,913 \mathrm{kcal} / \mathrm{kg})$. The proximate composition of the diets is shown on table 6 . Tables 7 and 8 revealed the fibre fractions of the diets (starter phase (2) and finisher diets), such as
ADL, ADF, NDF, Cellulose and hemicellulose. The performance characteristics of the broiler chicks is shown on table 9, with the values for initial body weight of the birds $(100.00 \pm 107.0)$, body weight gain $(1.65 \pm 0.10 \mathrm{~kg})$, mean feed intake $(4.60 \pm 0.92 \mathrm{~kg})$, feed to gain ratio $(2.10 \pm 0.63)$ and dressing percentage $(62.00 \pm 10.22 \%)$ elicited.

Table 3: Gross Composition of Cassava Peel-Leaf Meal Based Diets Fed to Broiler Chicks

\begin{tabular}{lllll}
\multicolumn{5}{c}{ (Week 3-6) Starter Phase } \\
\hline Ingredient & $\mathbf{0 \% C P L M}$ & $\mathbf{1 5 \% C P L M}$ & $\mathbf{3 0 \% C P L M}$ & $\mathbf{1 5 \% C P L M}$ \\
\hline Maize & 50 & 42.50 & 35.00 & 27.50 \\
GNC & 11.00 & 11.00 & 11.00 & 11.00 \\
CPLM & - & 7.50 & 15.00 & 22.50 \\
Bone meal & 4.00 & 4.00 & 4.00 & 4.00 \\
Fish meal & 9.00 & 9.00 & 9.00 & 9.00 \\
PKC & 10.00 & 10.00 & 10.00 & 10.00 \\
Salt & 0.50 & 0.50 & 0.50 & 0.50 \\
Soya bean & 15.00 & 15.00 & 15.00 & 15.00 \\
Premix & 0.50 & 0.50 & 0.50 & 0.50 \\
Total & 100 & 100 & 100 & 100 \\
CP & 24.04 & 24.01 & 23.99 & 23.97 \\
ME Kcal/Kg & 2,878 & 2,856 & 2,840 & 2,838 \\
\hline
\end{tabular}

Table 4: Proximate Composition of Cassava Peel Leaf Meal Based Diets Adopted for Broiler Starter Chicks (3-5Weeks)

\begin{tabular}{lllll}
\hline Parameters & 0\%CPLM & $\mathbf{1 5 \% C P L M}$ & $\mathbf{3 0 \% C P L M}$ & $\mathbf{4 5 \% C P L M}$ \\
\hline Dry matter & 90.27 & 90.67 & 90.73 & 90.81 \\
Crude protein & 22.67 & 22.97 & 23.67 & 24.49 \\
Crude fat & 3.53 & 3.73 & 3.77 & 3.8 \\
Crude fiber & 3.88 & 5.21 & 5.61 & 5.68 \\
ASH & 6.55 & 7.21 & 7.37 & 7.58 \\
NFE & 53.66 & 51.55 & 50.31 & 49.22 \\
\hline
\end{tabular}

Table5: Gross Composition of Cassava Peel-Leaf Meal Based Diets Fed to Broiler Chicks at Finisher Phase (Week 6-9)

\begin{tabular}{lllll}
\hline Ingredient & $\mathbf{0 \% C P L M}$ & $\mathbf{1 5 \% C P M}$ & $\mathbf{3 0 \% C P L M}$ & $\mathbf{4 5 \% C P L M}$ \\
\hline Maize & 55.00 & 47.00 & 40.00 & 31.50 \\
GNC & 10.00 & 10.00 & 10.00 & 10.00 \\
CLP & - & 7.50 & 15.00 & 22.50 \\
Fish meal & 8.00 & 8.00 & 8.00 & 8.00 \\
Bone meal & 4.00 & 4.00 & 4.00 & 4.00 \\
PKC & 10.00 & 10.00 & 10.00 & 10.00 \\
Salt & 0.50 & 0.50 & 0.50 & 0.50 \\
Soya bean & 12.00 & 12.00 & 12.00 & 12.00 \\
Premix & 0.50 & 0.50 & 0.50 & 0.50 \\
Total & 100 & 100 & 100 & 100 \\
CP & 22.09 & 22.07 & 22.03 & 21.99 \\
MEKcal/Kg & 2,913 & 2,910 & 2,900 & 2,899 \\
\hline
\end{tabular}

Table 6: Proximate Composition of Cassava Peel-Leaf Based Diets fed to Broiler Finishers $(6-9$ Weeks)

\begin{tabular}{lllll}
\hline Parameters & 0\%CPLM & 15\%CPLM & 30\%CPLM & 45\%CPLM \\
\hline Dry matter & 9025 & 90.31 & 90.39 & 90.47 \\
Crude protein & 18.67 & 19.37 & 19.65 & 20.13 \\
Crude fat & 3.51 & 3.55 & 3.57 & 3.16 \\
Crude fiber & 3.92 & 3.96 & 4.15 & 4.23 \\
ASH & 6.52 & 6.71 & 6.89 & 7.05 \\
NFE & 56.72 & 56.72 & 56.13 & 55.45 \\
\hline
\end{tabular}

Table 7: Fiber Fraction Analysis of Cassava Peel-Leaf Based Diets Fed to Starter Chicks

\begin{tabular}{lllll}
\hline Parameters & 0\%CPLM & 15\%CPLM & $\mathbf{3 0 \% C P L M}$ & 45\%CPLM \\
\hline ADL & 5,09 & 6.75 & 6.88 & 7.06 \\
ADF & 17.4 & 22.92 & 22.92 & 23.28 \\
DF & 36.37 & 37.28 & 39.06 & 41.23 \\
Cellulose & 12.35 & 16.17 & 16.19 & 16.22 \\
Hemicelluloses & 18.93 & 14.36 & 15.99 & 17.95 \\
\hline
\end{tabular}


There has been a lot of attention on the use of conventional feedstuffs in livestock nutrition, which has adversely affected the price of animal products and protein consumption (Oluyemi and Robers, 2000). Assessment of poultry diet shows that some ingredients like maize, soya bean and fish meal are competed for between humans, animals and industry (Nsa et al., 2019). There is therefore, an urgent need to look for cheaper, available and voluntarily consumed alternatives for maize, which accounts for about $50 \%$ of the gross composition of animal feed (Akinfala et al., 2019).In Nigeria, one of the cheaper alternatives is cassava products, such as tuber, peel, leaf, sieviate and chaff, their choice is because of their all year round availability, ease of processing and acceptability by poultry (Agunbiade et al., 2012). The by products are common in cassava food processing industries, where they constitute environmental menace, thus resulting in environment pollution (Ashaye et al., 2007). The utilization of these products in animal nutrition is an idea that could impact positively on animal production. The cassava by products adopted are sourced after harvesting, thus allaying the fear of competition of animals with humans and industry. Cassava leaves are sourced after tuber harvesting, while the peel is the bark of the tuber, these products are sundried after collection, to reduce their levels of anti-nutritional factors. Cassava leaf and peel were mixed in equal proportions by weight to evolve cassava peel leaf meal (CPLM), which has moderate level of crude protein $(18.93 \%)$. This was incorporated into broiler diet to evaluate performance. The diets compounded and adopted were adequate in nutrients for the physiological and developmental needs of the broilers chicks, based on the recommendation of (Oluyemi and Roberts, 2004 and Atteh, 2004). At the starter phase, the crude protein value of the feeds was about $24.00 \%$, while the metabilizable energy values was about $2850 \mathrm{kcal} / \mathrm{kg}$, the same M.E range was maintained at the finisher phase, with a lower crude protein value $(21.99 \%$ $22.09 \%$ ). These levels of nutrient and energy are effective, considering the energy protein ratio of the diets, which is important, to avoid nutrient wastage, high cost of feed, protein energy imbalance and heat burden on the broiler, due to excess crude protein, which will require more energy to digest (Iji et al., 2008 and Atteh, 2004).In order to ascertain the quantity and quality of fibre of CPLM, the crude fibre content and profiling were carried out. The fibre profile elicited the NDF, which is the bulk fibre, ADF (acid detergent fibre) which is the soluble fibre and ADL (acid detergent lignin) which is the insoluble or structural fibre. The proportion of the ADF of the NDF determines the ease of the fibre digestibility; coupled with the cellulose component. Cellulose and hemicelluloses are inhibitory to digestion of other nutrients (Hollister, 1991). It is important to note that the level of fibre in monogastric nutrition must be moderate, in order to optimize intestinal motility and its health benefit of cleaning of the gut. An elevated level of crude fibre (6.1 to $15 \%$ ) has been implicated in the significant reduction of feed conversion, feed intake and weight gain (Hoilister, 1991, Hetland et al., 2001 and Jimenez-Mireno et al., 2009).

Table 8: Fibre Fraction Analysis of Cassava Peel-Leaf Based Diets Fed to Finishers (Broilers)

\begin{tabular}{lllll}
\hline Parameters & 0\%CPLM & 15\%CPLM & 30\%CPLM & 45\%CPLM \\
\hline ADL & 4.37 & 4.52 & 4.63 & 4.75 \\
ADF & 17.38 & 18.73 & 18.92 & 19.34 \\
NDF & 31.72 & 33.94 & 39.94 & 35.73 \\
Cellulose & 13.01 & 14.21 & 14.29 & 14.59 \\
Hemicelluloses & 14.34 & 15.21 & 14.82 & 16.39 \\
\hline
\end{tabular}

\begin{tabular}{llllll}
\multicolumn{5}{c}{ Table 9: Performance Characteristics of Broiler Chicks Fed Cassava Peel-leaf Mixture Raised Diets } \\
\hline Parameters & $\mathbf{0 \% C P L M}$ & $\mathbf{1 5 \% C P L M}$ & $\mathbf{3 0 \% C P L M}$ & $\mathbf{4 5 \% C P L M}$ & SEM \\
\hline Initial body weight $(\mathrm{g})$ & 100.00 & 105.00 & 101.00 & 107.00 & 6.50 \\
Average body weight gain $(\mathrm{Kg})$ & 1.75 & 1.70 & 0.69 & 1.68 & 0.20 \\
Mean fed intake $(\mathrm{Kg})$ & $3.68^{\mathrm{c}}$ & $3.83^{\mathrm{b}}$ & $3.98^{\mathrm{b}}$ & $4.60^{\mathrm{a}}$ & 0.15 \\
Feed to gain ratio & $2.10^{\mathrm{b}}$ & $2.32^{\mathrm{b}}$ & $2.34^{\mathrm{b}}$ & $2.73^{\mathrm{a}}$ & 0.2 \\
Dressing\% & $73.00^{\mathrm{a}}$ & $72.00^{\mathrm{ab}}$ & $70.00^{\mathrm{b}}$ & $69.00^{\mathrm{b}}$ & - \\
\hline
\end{tabular}

The diets adopted at the starter and finisher phases in this trial were not compromised in quality, the fibre contribution of the CPLM was not deleterious since the values were within recommended range, (Hollister 1991). The performance parameters evaluated revealed that feed intake in this trial increased $(\mathrm{P}<$ 0.05 ) as the level of CPLM inclusion increased, attributable to the dilution of nutrient in the feed, which resulted in compensatory feeding in order to meet the nutritional need of the mammals (Hetland et al., 2001, Akinfala et al., 2019 and Kehinde et al., 2019). The value of feed to gain ratio $(2.10-2.73 \mathrm{~kg})$ is very promising, based on the reports of Oluyemi and Roberts (2001), Atteh (2004) and Kehinde et al., (2019). This has allayed any fear of adverse effects of CPLM in terms of anti-nutrients, Values of the carcass yield obtained were within range reported by Oluyemi and Roberts (2001) and higher than $54-59 \%$ reported 
in rabbits by Shaahu and Tibough (2019), 50\% for lambs and goat, but lower than $77-81 \%$ reported for turkey. It is evident that broiler chicks can favourably utilize diets containing CPLM up to $45 \%$ as replacement for maize to obtain favourable performance.

Conclusion: Composite cassava peel leaf meal (CPLM) derived from cassava wastes (peel and leaf) was favourably utilized by broiler chicks at $(0,15,50$, and $45 \%)$ ) as replace meant for maize without any deleterious effect on their performance indices, with additional benefits of wealth creation, improved environmental sanitation and enhanced human protein consumption.Its adoption by poultry farmers will reduce maize in broiler nutrition by $45 \%$.

\section{REFERENCES}

Aguihe,PC; Kehinde, AS; Chikezie, J; Abdulwahab, S., Adelakun KM; Joshua, DA (2020). Effect of Cocktail and Yeast combination on blood heamatology and biochemistry of Japanese Quails fed processed Yam peel meal based diets. J. Forestry Res. Manage. 17 (2):17-26

Aguihe, PC, Kehinde, KS, Babatunde, TO; Iyayi, EA (2015). Effect of supplementation of Cassava peel meal based diet with enzyme maxigrain on performance, apparent nutrient digestibility and economics indices of broiler finishers. Nig. J. Animal Product.41:100-109

Agbede SO, Ajaya. K; Aletor, VA (2002). Influence of Roxazyme $G$ supplementation on the utilization of Sorghum dust-based diets for broiler production. NSAP conference, March $17^{\text {th }}-21^{\text {st }}$ Federal University of Technology, Akure. Pp105108

Agunbiade, JA; Bello, RA (1997). Cassava peel in balanced diets for weaned rabbits. Proceedings, $22^{\text {nd }}$ Annual conf NSAP PP101-103

Akinfala, EO; Tewe, OO (2004). Supplemental effects of feed additives on the utilization of white cassava plant by growing Pigs in the Tropics. Livestock Research for Rural development.

Akinfala, EO; Amusan, KO; Adeyemi, MA (2019). Characteristics of Carbohydrate fractions of Cassava plant meal and its utilization by growing Pigs. Nig. J. Animal Product.46 (1):77-84.
Jiminez-Moreno, EA. JM, Gonzalez-Alvarado, A Gonzalez-Serramo, R,Lazaro; G.G Mateos (2009). Effect of dietary fiber and fat on performance and digestive traits of broilers from 1 to 2 days of age. Poultry Sci. 88:2562-2574

Kehinde KS (2009). Utilization of Cassava byproducts by Snails (Archachatina marginata Swainson). A Phd thesis submitted to the department of Animal Science, University of Ibadan, Nigeria p17

Kehinde, AS., Aguihe PC; Samuel, KU (2019). Effect of Maxigrain enzyme supplementation on blood chemistry of growing Japanese Quail fed Sundried Yam peel meal based diet. Nig. J. Animal Product.16 (1):107-115

Nsa, EE; Ukoha, OA; Onunkwo, DN (2019). Growth response, nutrient digestibility and cost benefit of feeding growing rabbits with selected agro industrial by-products-based diets. Nig. J. Animal Product.16 (1):85-93.

Olomu, JN (2011). Monogastric Animal nutrition principles and practice Jachern Publication, Benin Nigeria pp20-150

Oluyemi, JA; Roberts, FA (2004). Poultry production in warm wet climate. Spectrum books Ltd Ibadan, Nigeria pp24-49.

Shaahu, DT; Trough, SM (2019). Effect of replacing Maize with graded levels of sweet Potato VineCassava composite meal on growth performance, nutrient digestability, Carcass characteristics and economics of production of weaned rabbits. Nig. J. Animal Product. 16(1):116-123.

Steel, RG; JH Torrie (1980). Principles and procedures of statistics. A biometric approach $2^{\text {nd }}$ edition. $\mathrm{Mc}$ GramHill Book Co

Vansoest, PJ, Robertson, JB; Lewis, BA (1991). Methods of dietary fibre, neutral detergent fibre and non-starch polysaccharides in relation to animal nutrition. J. Dairy Sci. 74:3583-3597 